\title{
Among the Tribes of Shasta County
}

Robert P. Merges

Robert Ellickson. Order without Law: How Neighbors Settle Disputes. Cambridge, Mass.: Harvard University Press, 1991. Pp. ix+302. \$39.95.

Empirical research reminds me of that old saw about the weather: everyone talks about it, but no one does anything about it. Judging by his new book, Robert Ellickson must think the same thing. If legal academics read it and emulate its approach, even a little, the world-or at least that portion of it found between the covers of law reviews-will be a better place.

In Order without Law, Ellickson builds on the research behind his article "Of Coase and Cattle,"' which struck me as a classic when it was published in 1986. The point of the article was that people do not bargain based on their initial legal entitlements (as the Coase Theorem predicts) but instead work out exchanges based on nonlegal social norms. This was an interesting point, but (like others) I never took Coase's parables too seriously as predictors of actual behavior, choosing instead to view them as thought experiments about more abstract principles. Instead, what I liked about the article was how Ellickson made his point: with real observations of real people engaged in real disputes. When I finished the article I had a sudden urge to check my fences and scrape the mud off my boots. Honestto-God fieldwork in a law review!

In his new book, Ellickson goes far beyond "Coase and Cattle." First, he reports the results of inquiries in Shasta County, California, on disputes other than those stemming from cattle trespass, namely, joint maintenance of fence boundaries and cattle-related highway accidents. Second, he mixes in discussions of other empirical and quasi-empirical research on 
topics as diverse as the practices of whale catchers in the 19th century and photocopying of copyrighted materials by law professors. Third, he pulls together all his observations to construct a taxonomy of social control ranging from the most informal and nonlegal forms (e.g., self-regulation through conscience) up to formal law itself. And finally, he attempts to explain the emergence of many of the social norms he observed by use of game theory, especially recent work describing the emergence of cooperative behavior from multiple self-interest agents.

In short, Ellickson has labored mightily to embellish his approach in "Coase and Cattle" both by fitting his observations into an overall view of social interaction and by trying to describe why these norms emerged and not some others.

\section{WHAT'S NEW?}

The first thing I want to know when I pick up a new book is what it says that no other book can tell me. In Ellickson's book there is plenty that is new for this book's audience, although overall-as the author admitsmuch of what he says has been said before by sociologists, anthropologists, and other social scientists.

Certainly most everyone knows that "law" covers more ground than formal statutes, cases, and administrative rulings. We have known that at least since the demise of the Medieval Glossiters, quite possibly long before. In any event the various voices now known as realism were fairly united on the point. The problem is, as we also know, that as often as we hear it we ignore it. Ellickson is reminding us-once again-that law does not begin and end at the library door (or, more apropos for me at least, at the Lexis prompt). This is the legal academic's equivalent of "eat your vegetables"; something we all know, but have to be reminded of occasionally. Ellickson does a good job of this, and he does it in the most convincing way: by example. He shows that fieldwork is integral to researching the norms of social control that make up the world of nonformal law. By explaining clearly how he did his fieldwork and what he found, Ellickson provides a simple model to emulate in conducting this kind of research. ${ }^{2}$

2. At least one other law and economics scholar has ventured into the field. See Robert D. Cooter, "Inventing Market Property: The Land Courts of Papua New Guinea," 25 Law $\mathcal{E}$ Soc'y Rev. 759 (1991). Cooter surveyed the transition from customary, clan-based landholding in Papua New Guinea to formal real estate transactions. While Cooter uses some of the same models to describe customary social interactions (e.g., game theory "evolution of cooperation"), his study focuses on a fearure not present in Ellickson's book: the response of custom and formal law to changing conditions, in his case, the growing industrialization of the land-based economy. See id. at $783 \mathrm{n} .62$ ("tit-for-tat" model; custom is efficient); at 788 ("Perhaps my most important general finding in studying the land courts is that custom lives and adapts to novel situations"). Ellickson, by contrast, studies a mostly static set of economic phenomena. In a more recent article, however, he does suggest that 
The most striking finding reported in the book comes from the research behind the "Coase and Cattle" article. Ellickson set out to test the Coase Theorem by looking for an actual instance of what Ellickson calls one of Coase's "parables"-the farmer-rancher exchange. You may well be familiar with Coase's hypothesis that when a rancher's cattle routinely damage a neighboring farmer's crops, the rancher and farmer will, in the absence of high transaction costs, achieve a bargain under which their joint output ${ }^{3}$ is the same whether the rancher was legally liable or not. (Coase did say that the legal rule would determine which party paid how much and what effect these payments would have on the output by each of particular products. ${ }^{4}$ ) Ellickson found that not only was the Coase Theorem not borne out-a result Coase himself might anticipate because of his belief that the zero transaction costs assumption is usually unrealistic ${ }^{5}$ but that this was so for a very interesting reason. It's not that the law is irrelevant because people bargain around it whatever its content. It's that they ignore its content. People don't go around the law, like a big but negotiable obstacle: they go right through it, as if it were invisible-which to most people most of the time it is. ${ }^{6}$

This finding grows out of Ellickson's observation that in dealings between cattle ranchers and their neighbors, decisions regarding who pays

the efficiency criterion can explain how close-knit groups respond to dynamics. See Robert Ellickson, "Property in Land," - Yale LJ. 13-, 1397 (19-) ("The central positive thesis of this Article is that a close-knit group tries to create, through custom and law, a cost-minimizing land regime that adaptively responds to changes in risk, technology, demand, and other economic conditions").

3. That is, the total economic value of their joint output, measured in dollars in Coase's examples.

4. That is, assigning liability to one party or the other may affect how much of each good or service is produced; it just will not affect the total value of all goods and services produced. Others following Coase have argued that there will be distributional effects from different allocations of rights. "Of course, the initial allocation of rights always matters from the perspective of income distribution. To illustrate, if efficiency requires the railroad to be free from an injunction, granting the farmers the right to be free from injunctive relief will motivate the railroad to try to buy this right. The purchase is a cost to the railroad and income to the farmers. Conversely, granting impunity to the railroad will save it the cost of purchasing the right and deprive farmers of the income from selling it." Robert D. Cooter, "The Coase Theorem," in The New Palgrave: Allocation, Information, and Markets 64, 67 (New York: Norton, 1987). Coase himself denies this, however. Ronald H. Coase, "Notes on the Problem of Social Cost," in John Eatwell, Murray Milgate, \& Peter Newman, eds., The Firm, the Market, and the Law 157, 172 (Chicago: University of Chicago Press, 1988) ("Coase, 'Notes' ") (arguing that assignment of legal right will be reflected in the relative costs of farm land and railroading, and therefore the parties will wind up with the same distribution of resources in either case).

5. See Coase, "Notes" at 174 ("The world of zero transaction costs has often been described as a Coasian world. Nothing could be further from the truth. It is the world of modern economic theory, one which I was hoping to persuade economists to leave").

6. Especially where close-knit groups-the ones of interest to Ellickson-are involved. An exception, of course, is where law comes to reflect community practices, in which case it is arguably redundant. Cf. Richard M. Brown, No Duty to Retreat (New York: Oxford University Press, 1991) (discussing American law and custom of right to defend the home from intruders). 
how much for damage and damage prevention are the same regardless of the legal rule. It makes no difference whether the bargainers reside in an "open range" district, where damage from stray cattle must be borne by the neighbor, or a "closed range" district, where the cattle rancher must pay (at 43-44). In both cases, the working norm is that "an owner of livestock is responsible for the acts of his animals" (at 53). Although most cattle ranchers know which kind of district they are in, and have a sketchy idea of the legal liability that follows from this, it makes no difference. The stylized account in Coase's article predicts that the joint output of the neighbor and rancher will be the same regardless of the legal rule. The "side payments" will differ, and thus the cash positions of the parties will differ, but the overall production will stay the same. Ellickson's observation goes further: that the respective behavior of the parties does not change a whit; that the legal rule is totally irrelevant. Ellickson: "[T]respass conflicts are generally resolved not in the 'shadow of the law' but, rather, beyond that shadow" (at 52; his emphasis).

Thus the "legal irrelevance" aspect of the Coase theorem is, Ellickson concludes, even more true than Coase's famous article makes out.

This is not to say that this behavior is not rational. Ellickson emphasizes that, in the context of a rural county whose residents often interact for a variety of reasons, it makes sense not to bargain over each instance of cattle trespass. The trespass norm is that the rancher is responsible for his or her cattle. But this is part of an overarching norm of good neighborliness. It is part of a larger system of informal "accounts" which are balanced over time by reciprocal acts of neighborliness. Ultimately, it is this frequent interaction-the "repeat play" nature of "bargaining" - that renders the law irrelevant and social norms paramount. (Given that the damage from most ranchers' cattle will likely fall on rural neighbors, it is worth

7. Cf. David M. Engel, "The Oven Bird's Song: Insiders, Outsiders, and Personal Injuries in an American Community," 18 Law $\mathcal{E}^{\prime}$ Soc'y Rev. 551 (1984) (residents of small Illinois town believe litigation is bad and so settle everything without recourse to formal legal apparatus).

8. This theme is an old one in sociology, and it has found new adherents recently in law as well. See Sally Falk Moore, "Law and Social Change: The Semi-autonomous Social Field as an Appropriate Subject of Study," 7 Law \& Soc'y Rev. 719 (1973); Janer T. Landa, "A Theory of the Ethnically Homogenous Middleman Group: An Institutional Alternative to Contract Law," 10 J. Legal Stud. 349 (1981); Lisa Bernstein, "Opting out of the Legal System: Extralegal Contractual Relations in the Diamond Industry," 21 J. Legal Stud. 115 (1992); Douglas W. Allen \& Dean Lueck, "The 'Back Forty' on a Handshake: Specific Assets, Reputation, and the Structure of Farmland Contracts," 8 J.L. Econ. \& Otg. 366 (1992). Cf. Jerold S. Auerbach, Justice without Law? (New York: Oxford University Press, 1983) (documenting evolution of informal control mechanisms and attempts by lawyers to undermine or appropriate them). See generally Richard Swedberg, Economics and Sociology (Princeton, N.J.: Princeton University Press, 1990) ("Swedberg, Economics and Sociolog") (collecting interviews with scholars working at the increasingly fruitful intersection of these swo fields). 
asking why legislation on this topic was ever enacted; if everyone was satisfied, why would the legislature pass a bill on the subject?)

As Ellickson notes, it was Robert Cooter who first recognized that perhaps the most important feature of Coasian bargaining is that the bargain does not take place in a well-established market.9 The bargain that emerges is a function of the value of both parties' economic activities, as well as the cost of the parties' interference with each other. The bargainers have only a sketchy notion of the others' valuation. Strategic behavior follows. This contrasts sharply with the examples given by Coase, which assume a straightforward bargain once the interference between the parties is recognized and the right is assigned. Of course, one of Coase's goals was to highlight transaction costs, not assume them away. ${ }^{10}$ Even so, the "strategic" nature of Coasian bargaining has only recently been elaborated.

Strategic bargaining is only one of a number of transaction costs that must be considered. And as Ellickson demonstrates, a detailed consideration of the entire range of transaction costs yields some useful insights in the context of informal exchange. For instance, the high transaction costs of using the legal system in the first place explain why in many cases disputes are settled informally. Another example is the cost of calculating the value of each exchange in an ongoing series of transactions. "Focal point" solutions, together with repeat play, make such calculations unnecessary, and indeed their cost is one rationale for engaging in repeat transactions in the first place.

One problem with this line of thinking, however, is that the transaction cost approach is so flexible as to border on the formless at times. Take, for example, the assumption of costly information. Ellickson says this leads to the use of "focal points" in bargaining situations; instead of detailed calculations, we get "I'll pay this time, you pay next" or "we'll split the tab." But costly information might lead one to predict that in some situations no calculation-not even one dictated by a "focal point"-is possible at all. This seems to be true, for instance, in the obvious case of everyday courtesies such as greetings. Since it is impossible to identify the value of a greeting, we would be loath to say that greetings are exchanged for economic reasons. Yet the same point might be made about any exchange that appeared difficult to cast in economic terms. That is, we would have a ready-made excuse for the nonapplicability of the economic model of exchange whenever the transaction costs (in this case, valuation costs) were high. At least some component of the decision when to treat a

9. Robert D. Cooter, "The Cost of Coase," 11 J. Legal Stud. 1, 23 (1982): "The error in the bargaining version of the Coase Theorem is to suppose that the obstacle to cooperation is the cost of communicating, rather than the strategic nature of the siruation. Bargainers remain uncertain about what their opponents will do, not because it costs too much to broadcast one's intentions, but because strategy requires that true intentions be disguised."

10. See note 5 supra. 
particular exchange as "economic" or "purely social" is itself socially mediated rather than strictly based on rational assessments. In other words, valuation costs may be high for some "intrinsic" reason, like the cost of splitting a restaurant check; or they may be high because of some social convention, such as "we don't normally place a dollar value on greetings." Where social norms pressure us not to put a dollar value on something, that thing will be expensive to value. Hence the costs of exchanging that thing will be high. ${ }^{11}$ The upshot is that saying transaction costs are high does not really state a purely economic rationale for the rarity of that thing's valuation. It merely restates the social norm or, perhaps more accurately, states the economic impact of the social norm. One might well conclude that this question of which norms can be accounted for in economic terms is quite sticky indeed and that, despite the usefulness of transaction cost analysis in some contexts, it runs into some problems here.

In any event, the discussion of transaction costs is only one example of the methodological currency of the book. Besides transaction costs, Ellickson dwells at length on game theory, especially the literature on the evolution of cooperation. By some standards, looking for transaction costs in neighborly interactions in a rural county is actually quite modest, given that these ideas have been used in recent years to explain all manner of

11. For an example of this, contrast two common social practices in the context of restaurant meals: paying tips and splitting checks. Many people follow a common procedure for calculating tips; they take $10 \%$ of the meal price, which is easy to calculate, then they add $50 \%$ to this amount, easily done by adding half again the original $10 \%$ amount. The result is a $15 \%$ tip, calculated according to a well-known and widely used procedure. Splitting dinner checks, on the other hand, is a different matter. Although in many cases two or more people who share a meal attempt to divide up the dinner check to reflect the actual cost of the food eaten by each, in many other cases they follow a different rule, usually either (1) one person pays all, or (2) each pays the same amount, regardless of their actual meal (i.e., they divide the total check by the number in the party). Significantly, in my experience at least there is no strong correlation between the complexity of the calculation or the number of people in the party and the frequency with which the diners attempt to divide up the check according to what each one actually ate. Even when the calculation is relatively simple, in other words, precise apportionment of costs is sometimes eschewed. It is not therefore a simple matter of information costs. There is more going on, something in the nature of a social convention governing the various dining situations. At the same time, one can imagine a relatively simple rule that might be applied in such situations; say, splitting the total cost according to such easily observed features of each diner's meal as how many courses each had or the like. Alternatively, one can imagine a simple rule whereby the total check is divided in half, and then $20 \%$ of the total is added to one half and the one or two or three largest eaters (agreed on by consensus) would then pay that larger "half." The point here is that these imaginary rules, and others like them, if as well known and widely used as the tip rule, could make the procedure for dinner check splitting just as routine as the calculation of a tip. It is arguable at least that there is no iron physical law, or logical principle, that explains the differences between social norms that we observe in the two situations. In other words, it is at least possible that the low information cost does not dictate, but in fact follows from, the social norm. A recent dinner with friends from a country where dinner patrons do not tip supports the point; they were surprised that I could calculate the $15 \%$ tip almost without thought, until I told them about the common procedure described above. 
things, including nothing less than the rise of Western civilization. ${ }^{12}$ Game theory is even more advanced, having been identified as the underlying logic behind not only law, government, and society but also biblical stories and future encounters with alien beings. ${ }^{13}$ Ellickson is careful not to extend these methodologies quite so far, perhaps out of a sense that such an exercise might someday haunt him, as past fads are wont to do. This is a good feature of writing a book, it seems to me: it inspires a sense of perspective. No one wants to open a book years later and see herself wearing the intellectual equivalent of a Nehru jacket, hula hoop, or mood ring.

Likewise, when Ellickson turns to fitting his observations into an overall framework, he is for the most part very clear about what he is doing and why. While he is of course not the first to construct a taxonomy of social control, ${ }^{14}$ he does the job in an admirably straightforward manner. It is helpful because it shows that he has thought about what he is observing and its place in the entire universe of social control and because he describes once again the limited place of the formal legal rules most of us study most of the time.

As already mentioned, Ellickson is hardly content to report and cata$\log$ his observations. His real interest is to say why these norms, rather than others, emerged. In other words, he wants to fit his observed norms into a theoretical structure, to account for them, and ultimately to use his account to predict what other norms will look like.

His basic hypothesis reflects bedrock law and economics thinking. The norms that emerge, he predicts, will maximize welfare in a close-knit group. Not only does he apply this hypothesis to the norms he observed, but he also challenges others to apply it in other contexts to other norms. He wants to apply the law and economics rational account of behavior to nonformal spheres of social control. One way of viewing his enterprise, in fact, is that he wants to expand the "law" in law and economics to include a wide variety of law-like behaviors, including social norms of all stripes. Ellickson wants to do for law and economics what the "sociological juris-

12. See, e.g., Douglas North, Structure and Change in Economic History (New York: Norton, 1981). The picture presented in this book has been filled out to some extent in subsequent work; see Douglas C. North, Institutions, Institutional Change and Economic Performance (New York: Cambridge University Press, 1990) (arguing that institutional features, most important their impact on transaction costs, explain differential rates of development). Cf. G. Shibata, D. Tse, I. Virtinsky, \& D. Wehrung, "Do Norms of Decision-Making Affect Performance of Japanese Firms? An Exploratory Study of Medium and Large Firms," 12 Mgmt. \& Decison Econ. 135, 144 (1991) (finding positive relationship between management style that fosters trust and economic performance).

13. See, e.g., Steven J. Brams, Biblical Games: A Strategic Analysis of Stories in the Old Testamene (Cambridge, Mass.: MIT Press, 1980); id, Superior Beings-If They Exist, How Would We Know? Game-theoretic Implications of Omniscience, Omnipotence, Immortality, and Incomprehensibility (New York: Springer-Verlag, 1983).

14. See, e.g., Donald Black, The Behavior of Law (New York: Academic Press, 1976), whose concept of "social distance" is closely related to Ellickson's taxonomy of social control. 
prudence" realists did for law in general-remove its formal law-centered bias. Ellickson explicitly denigrates current research as much too "legalcentric." 15 He leads by example, showing what non-law-centered research looks like.

Before turning to a discussion of the importance of Ellickson's chief finding and major hypothesis-that norms maximize welfare in close-knit groups-I want to add another point about the empirical research at the heart of the book. Ever since some Yale faculty member cracked a joke about counting the coins in parking meters, empirical research has been viewed as drudgery-the academic equivalent of folding laundry or raking leaves. Ellickson's work is a tonic for these complaints, on two levels. First there is the Shasta County fieldwork, whose appeal should be clear for anyone who has ever found themselves in the shadow of the Cascades. Second there is his research on the property right norms pertaining to whale harvests in the 19 th century. This research refutes emphatically the notions that (1) empirical research has to be numbingly exhaustive to be relevant; (2) empirical research is therefore expensive; and (3) historical and even caselaw materials cannot be used as empirical sources. I have found in my own work on patent law that historical materials and caselaw can be used-with care-to give empirical weight to arguments. ${ }^{16}$ Again, Ellickson leads by example on this score.

\section{A CONCEPT NAMED NORM}

Central to Ellickson's enterprise is the notion of a norm. Norms are the patterns of behavior he observed in Shasta County and elsewhere, usually dispute-resolving behavior. And they are what must be fed into the explanatory engine of economics for theoretical explication. ${ }^{17}$ So a few words are in order on the notion of norms.

I must say at the outset that Ellickson's empirical persona does not always agree with his theoretical one. The divergence comes in the discussion of various types of norms. For instance, when describing how Shasta County neighbors split the cost of fence building and repair, he notes that by convention they do not ascribe a direct dollar value to their labor. Thus

15. The legal centrism tradition, says Ellickson, can be traced to Hobbes (ar 138). Then Calabresi and Melamed identified "the state" as the sole source of rights to be exchanged (at 139). More recently, law and economics scholars such as Stigler, Polinsky, Priest, and Shavell have assumed complete knowledge of the law-another form of "legal centrism," according to Ellickson (at 140).

16. Robert P. Merges \& Richard R. Nelson, "On the Complex Economics of Patent Scope," 90 Colum. L. Rev. 839, 860-62 (1990).

17. This may strike some as a rather positivistic definition of a norm-as opposed, say, to one where norms are defined as deep-seated beliefs, attitudes, etc., that cause observable behaviors. Whatever one calls these observed behavioral patterns, they are what Ellickson set out to explain. 
the splitting takes one of three forms: (1) taking turns paying all the expenses; (2) one pays for materials, the other supplies labor; or (3) each takes responsibility for half of the length of the fence. There is no attempt to put a market price on the value of the labor. Ellickson simply reports the commonsense notion that in this and other situations putting a dollar value on a contribution is thought to inject an air of coldhearted commercialism into an otherwise friendly transaction.

In later chapters, when describing his hypothesis of welfare-maximizing norms, he does not dwell on observations such as these. He does distinguish between "foundational" norms, such as the existence of private property and the wrongness of theft, and the "workaday" norms he is interested in (at 174). In his view, foundational norms are "exogenous" rules that enable exchange (id.). ${ }^{18}$ But this distinction between foundational and workaday rules leaves some problems unresolved. One can understand why some "ground rules for exchange" must be taken as givens. But what about the related question of which kinds of things will be subject to which modes of exchange? The fence repair norms might well maximize wealth, given the givens; but one is left to wonder: Why are these the givens? In other words, is it possible that some aspects of this norm are "foundational" or culturally embedded? Do neighbors refuse to value labor because it is inherently difficult to value, or because it is just not neighborly to do so? Ellickson assumes the former, but I for one was left wondering.

Sociologists have not done any better at predicting the existence of norms such as the "no market valuation of labor" norm in Shasta County. But at least they have cataloged a good number of these norms. For instance, it is widely noted that in some cultures one who kills a person can repay the person's family. ${ }^{19}$ One wonders how Ellickson would handle this. Perhaps it is a feature of the "foundational" norms making up the society-a statement of what is and is not a proper subject of exchange. Yet if this is so, then the same thinking might be applied to the fencerepair norms. If neighbors in our society "just don't do that sort of thing"-put a value on their labor-then perhaps other features of this exchange likewise reflect culturally embedded norms rather than wealthmaximizing norms that have evolved over time. In any event, finding the

18. Ellickson also expresses "agnosticism" about norms of pure charity, saying they are outside the scope of his hypothesis of wealth maximization. Indeed, he also states the flip side of this: that he assumes no distributive concerns infect the content of the norms he examines (at 177).

19. Allan Horvitz, The Logic of Social Control 49 (New York: Plenum Press, 1990) ("Horvitz, Social Control") (different societies define "compensable" wrongs differenty; some hold that murder is compensable, others say it threatens a "core value" and requires a more severe punishment). 
proper level of generality at which to apply Ellickson's central hypothesis seems like a tricky business to me.

Even so, a word in Ellickson's defense is in order. Although he generalizes a good bit from his observations, these observations center on activities where objective economic facts have a good deal of influence on the neighbors' behavior. Fencing is expensive; labor is limited. If these economic factors affect behavior-as they appear to-then invoking economic theory to explain them is a reasonable thing to do. Even the norm that neighbors don't charge for their time might have an economic rationale. For instance, although a good argument could be made that since any laborer can repair fences, the labor rate should equal the going rate for day laborers, ${ }^{20}$ it might not make sense to value a rancher's time at this rate. Perhaps this has something to do with the idiosyncratic nature of each piece of land or with lower communication/cooperation costs between repeat-player neighbors. In any event Ellickson seems too willing to assume that this practice is dictated by economic logic. In other words, the book invites at least a bit more attention to the line between exogenous "foundational" norms and those "workaday" norms that can be tested against the wealth-maximizing hypothesis.

Some sociologists would no doubt go further, disagreeing with Ellickson's basic account of the logic of norms. While Ellickson sees norms as primarily adapted to efficiently allocate valuable commodities, a good number of contemporary sociologists would no doubt reply that he has it exactly backward: norms dictate which commodities have economic value in the first place. So a "norm" that negative gossip is a bad thing (which Ellickson uses as an example of informal social control), rather than being positive or irrelevant, is what makes this "enforcement" mechanism effective. Likewise, primitive marriage exchanges are based on social definitions of appropriate mates, which reduces the available pool of mates and therefore increases their value. Ellickson does not go into how these value-defining norms emerge, perhaps because the norms he is most concerned with center on commodities having what he (and may others) would consider fairly "objective" values-food- and income-producing assets such as cows and land. Nonetheless, because he proposes to generalize so extensively from his case studies, the emergence of at least some value-defining norms regarding less apparently "objective" commodities remains a challenge to

20. Under this argument, as in the earlier footnote discussing social norms on tipping and dinner checks, the reluctance to pay one's neighbor the going labor rate for fence-repair work is an outgrowth of norms regarding what it means to be a neighbor, rather than of the difficulty of valuing labor. If this norm made such valuations unusual, such unfamiliarity would of course contribute to the cost of the calculation. But the costliness of the calculation would follow from, and not be the cause of, the norm. Note that since presumably most ranchers hire day labor at one time or another, they know the going rate or can easily find out. This at least eliminates one cost in ascertaining a reasonable labor rate for fence repair between neighbors. 
his wealth-maximization hypothesis. Surely the polar opposite position, that everything is culturally mediated, socially constructed, and therefore contingent, is at least as unhelpful. But just as surely, his short treatment of which norms are foundational and which can really be understood in economic terms leaves some unanswered questions.

Perhaps if he had attempted to limit his hypothesis of wealth maximization to only the "purely economic" sphere, Ellickson's book would have been shorter and less interesting, and the opportunities for generalization far fewer. And perhaps the division of the world into the economic and noneconomic is itself an unworkable social convention. But the point remains that after reading Ellickson's masterful and admirably clear empirical accounts, his broad hypothesizing does not always sit well.

\section{NORMS TO THE MAX (PROFIT)}

Despite these quibbles with the scope of his hypothesis, readers will no doubt be impressed with the comprehensiveness of the models that grow out of it. Ellickson sets out to use game theory to explain the internal logic of the reciprocal nonlegal norms he observed; his treatment of these models is exemplary. And if I am not mistaken, there seem to be a few new theoretical twists thrown into the models themselves.

The basic model is of course the Prisoner's Dilemma, which is as familiar to most consumers of legal academic work as citations to the interpretive theories of Gadamer. ${ }^{21}$ Ellickson builds on the basic model to

21. For those who have somehow avoided this business up until now: The following matrix captures the Prisoner's Dilemma. The point is that under the circumstances specified, the parties would both be better off if they cooperated, but because they are each worse off if they cooperate and the other doesn't, they won't-they will defect instead (the scenario explained below). This is captured arithmetically by the payoffs in the matrix. The figures in the upper left-hand corner (" $3 / 3$ ") represent the net gain to each from cooperating (i.e., $\$ 3$ each). The figures in the lower right-hand corner illustrate the gain to each if they both don't cooperate, i.e., they both defect ( $\$ 1$ each). The other two corners of the matrix represent the payoffs when one party cooperates and the other defects. In the upper right corner, A cooperates but B does not. The lower left corner represents the opposite situation.

$$
\begin{aligned}
& \text { Party } B \\
& \begin{array}{lll|l|}
\multicolumn{1}{c}{\text { Party } A} & \begin{array}{l}
\text { Cooperates } \\
\text { Cooperates }
\end{array} & \text { Defects } \\
\cline { 2 - 3 } & \text { Defects } & 3 / 3 & 0 / 5 \\
\hline 5 / 0 & 1 / 1 \\
\hline
\end{array} \\
& (x / y)=\text { (payoff to Party A/payoff to Party B) }
\end{aligned}
$$

Withour knowing in advance which strategy the other party will choose, it is only safe to defect-because of the risk you will get "burned" by cooperating while the other party defects. The classic example of a payoff structure like this is the case of the two criminal suspects captured and placed in different cells. Cooperating means refusing to confess to the crime (which is grear if the other party/prisoner also chooses this, and awful if she chooses to confess; you are punished extra, in this game, for not confessing). Defecting means confessing to the crime. The payoffs may be thought of as the value of various punishments, 
reflect the more complex interactions that occur when players play the game over and over again, and do so in a larger social setting, as neighbors do. These repeat players can be expected to behave quite differently from Prisoners faced with a one-time dilemma. As Robert Axelrod's ${ }^{22}$ influential simulations so convincingly demonstrated, cooperation can emerge from repeat-play interaction; this stems from the fact that defection in one round of the game can be punished by reciprocal defection in a later round. This, together with the fact that in this game cooperation always yields the highest of the available payoffs, is what leads to "the evolution of cooperation."

Ellickson adapts Axelrod's work three ways. First, instead of relying on the simple two-party model where only the players themselves can administer payoffs, Ellickson modifies the theory to place the game in a social setting, which adds an element of third-party sanction. Defection can be "punished" by larger social forces, rather than simply by "revenge" in the next round. The sanction can thus take the form of negative gossip, for instance, in addition to "self-help" by one of the parties.

Second, Ellickson adapts Axelrod's repeat-play game to reflect the fact that in some situations, one party's cooperation is more valuable than the other's. The context for this adaptation is Ellickson's discussion of cooperative fence repair. He observes that sometimes one of the two adjoining neighbors is more handy than the other or in some other way better positioned to provide the fence-repair service. This is captured in a game theory model Ellickson labels "Specialized Labor," in which the payoffs are structured so that total welfare is maximized not when both players cooperate (i.e., work), as in the Prisoner's Dilemma, but when one of the two (the cheaper labor provider) cooperates and the other shirks.

This is an interesting twist on the Prisoner's Dilemma; it appears to have some useful applications in law. As Ellickson notes, the basic insight is to fold the Calabresian "cheapest cost avoider" concept into a game theory model. ${ }^{23}$ This Specialized Labor game has already been employed on eminent domain problems by Clay Gillette; other applications will no doubt follow. ${ }^{24}$

The third major adaptation to Axelrod's basic framework is the addition of "account squaring" between rounds of play. This actually involves

e.g., 5 is that you go free, 3 is a short jail term, 1 is a fairly long jail term, and 0 is a very long jail term. You can see thar, taken together, the best outcome for the two prisoners would be $3 / 3$, which is the payoff if they both cooperate (i.e., do not confess). But since cooperating while your counterpart defects is disastrous, it is safer (i.e., gains you more regardless of what the other prisoner does) to defect (i.e., confess).

22. Robert Axelrod, The Evolution of Cooperation (New York: Basic Books, 1984).

23. See Guido Calabresi, The Costs of Accidents (New Haven, Conn.: Yale Universiry Press, 1970).

24. See Clayton Gillette, "Game Theory and Local Government Law" (working paper presented at Boston University Law School faculty workshop, April 1992). 
two extensions from Axelrod: (1) a measure of the account "debit" to be made when one cooperates and one's neighbor defects; and (2) the possibility of side payments and other account-squaring activities outside the context of the game.

The notion of a debit is not central to Axelrod's basic model; there players merely keep track of whether their opponent has cooperated. The response to defection (noncooperation) is simple: a corresponding defection in the next round. Ellickson, true to his observations, builds more complexity into his model. His "game" has many facets. It encompasses all the social interactions of neighbors and, by extension, any close-knit social group. Because there are differing magnitudes of defections, one's response to a defection must be calibrated. Thus by employing the notion of a mental account, one can keep track of the running balance and therefore gauge not only the type of response (cooperate or defect) but also its magnitude.

The second novel dimension of "account squaring" is the idea that players can settle their balances outside the context of the game-that is, between rounds. This is another way in which Ellickson tries to "situationalize" the repeat-play game, to place it in its social setting. It has the advantage of realism, certainly. Neighbors don't wait until the next fence-repair opportunity-the next round of the "fence game"-to repay a prior defection. They may exclude the defector from the next neighborhood social gathering, or let out their dog when they see the neighbor's cat, or whatever. Ellickson understands well that the myriad interactions between neighbors are not perfectly captured inside the neat lines of a game theory matrix.

But this very multidimensionality might be enough to raise questions about game theory models in this context. These issues are especially pertinent when Ellickson's work is compared to that of sociologists who have studied exchange.

The controversy over economic explanations of exchange is as old as sociology itself, originally pitting Emile Durkheim against Herbert Spencer. ${ }^{25}$ Even in the early 20 th century, some pioneering social scientists had discovered an underlying economic explanation for exchange. G. C. Frazer, for instance, wrote: "For under the surface alike of savagery [sic] and civilization the economic forces are as constant and uniform in their operation as the forces of nature, of which indeed, they are merely a peculiar complex manifestation."26

25. See Peter P. Ekeh, Social Exchange Theory: The Two Traditions 21, 43 (Cambridge, Mass.: Harvard University Press, 1974).

26. Quoted in Claude Levi-Strauss, The Elementary Structures of Kinship 138 (Boston: Beacon Press, 1969). 
This interpretation was not universal, however; others insisted on a split between social and economic exchange. In Bratislaw Malinowski's Argonauts of the Western Pacific, ${ }^{27}$ which describes the exchange of trinkets among indigenous peoples of the western Pacific as primarily a symbolic matter, we read: "[I]t is important to realize that in all forms of exchange in the Trobriands, there is not even a trace of gain, nor is there reason for looking at it from the purely utilitarian and economic standpoint, since there is no enhancement of mutual utility through the exchange."28 Malinowski says these exchanges demonstrate the importance of "giving for the sake of giving," a feature of all primitive exchange.

Ellickson refers to the work of another social science exchange theorist, Marcel Mauss, to support the discussion of Shasta County residents' "game strategy." Mauss argued that exchange in general, and especially gift giving, is not simply a matter of individual-to-individual transactions, but that the specific persons in the transactions represent their respective groups (clan, tribe, etc.). ${ }^{29}$ Thus there is an added complexity to exchange as it has been studied by sociologists: the fitting of an individual transaction into the overall relationship between groups. While Ellickson cites Mauss among other researchers who "hint at the pervasiveness of something like an Even-Up approach to social interactions" (at 228 n.45, citing Mauss), he does not delve into the subtleties of this literature.

Yet when describing the interactions between cattle ranchers and homeowners, Ellickson might have made use of Mauss's concept of group identity. It might, for instance, explain why some transactions were undertaken, although they were perhaps not wealth maximizing in isolation; the answer might lie in an attempt to keep relations between the groups smooth. At some level the game-theoretic "evolution of cooperation" literature could no doubt account for this. But it is left for someone else to give it a try. ${ }^{30}$

Moving on to the details of exchange, Ellickson takes what may be described as a "strong rationality" view of social interaction. That is, he believes the content of norms governing social exchanges as well as more economic transactions can largely be explained by reference to self-interest. ${ }^{31}$ As might be expected, however, sociologists occupy a wide range of

27. London: Routledge \& Kegan Paul, 1922.

28. Id. at 175. See also Christopher Healey, Maring Hunters and Traders: Production and Exchange in the Papua New Guinea Highlands (Berkeley: University of California Press, 1990) (trade in bird feathers used to symbolically constitute social relations).

29. Marcel Mauss, The Gift: Forms and Functions of Exchange in Archaic Societies, trans. Ian Cunnison (New York: Norton, 1967).

30. Mauss himself (id. at 11), however, appeared to have rather complicated view of exchange, describing it as contributing to a "spiritual bond" or basic moral framework that holds society together.

31. See, e.g., at 78, where Ellickson compares the norms governing fence-repair reimbursement with those applied to sharing the costs of dinner among friends. Recall, however, that Ellickson expressly excludes pure gif giving from his analysis (see at 176-77). 
positions on this issue; while Ellickson does not appear to do serious harm by simplifying, it is perhaps useful to note several points from the sociological literature.

Putting aside those who, in the tradition of Malinowski, believe in a steep wall between strictly economic exchange and social exchange, ${ }^{32}$ the main debate is over the degree to which social exchange can be explained in terms of economic motivations. What might be called the "strong economics" school holds that self-interest explains all, or almost all. By contrast, the "modified economics" or "weak economics" school keeps rational calculation as an important factor in explaining social exchange but adds other factors as well. Ellickson sees himself as a proponent of a rigorous "weak economics" view. He remains sensitive to the details of his own observations, even those without any apparent economic significance. ${ }^{33}$ Still, a sociologist might say that Ellickson espouses a stronger form of economic determinism than he believes.

A passage from a recent paper by the sociologist Tom Burns illustrates:

The norm of reciprocity with its partial open-endedness encourages social exchange partners to engage in $a$ variety of transactions-to exchange favors, advice, help, social support, and companionship. This diffuse spectrum of transactions-with potentialities for future transactions-makes any exact calculation extremely difficult, if not impossible, at the same time that it gives the partnership intrinsic significance. The relationship itself assumes considerable importance: namely, the potential giving, sharing, and receiving. This includes highly symbolic as well as instrumental forms of action. The exchange relationship-the partnership-typically does not depend on specific outcomes which in any given case cannot always be identified or, if identified, measured. ${ }^{34}$

This perspective leads Burns to claim that in social relations, people actually prefer to.elect a "game strategy" that costs them more. That is, the person prefers to pay more than the other person in the exchange. There is the hope of a diffuse payoff some time in the future in time of need. But

32. I have been told that this tradition is well represented in Randall Collins, Theoretical Sociology (New York: Harcourc, 1988).

33. This is in keeping with his own advice on these matters. See Robert C. Ellickson, "Bringing Culture and Human Frailcy to Rational Actors: A Critique of Classical Law and Economics," 65 Chi.Kent L Rev. 23 (1989).

34. Tom R. Burns, "Models of Social and Market Exchange: Toward a Sociological Theory of Games and Social Behavior," in Craig Calhoun, Marshall W. Meyer, \& W. Richard Scotr, eds., Structures of Power and Constraint: Papers in Honor of Peter M. Blau 129, 134-35 (Cambridge: Cambridge University Press, 1990). 
the key is that the immediately utility-reducing "strategy" is actually preferred without any current, concrete promise of gain. ${ }^{35}$

Note the differences between this model and Axelrod's celebrated "tit-for-tat" model, on which Ellickson draws. ${ }^{36}$ Tit-for-tat means cooperate first, then mirror exactly your "opponent's" move-cooperate if she does, don't cooperate (i.e., "defect" or "punish") if she does not. The "very weak economic" model just described contrasts significantly. In it, "partners" can be expected not only to cooperate but to sacrifice-to acturally work toward and expect a loss. Moreover, because the time frame is long, and the return payments so diffuse, the person will apparently sacrifice or cooperate more than once without expecting anything in return.

Ellickson takes a different view. For instance, consider his discussion of one exchange between two neighbors. One fixed a common boundary fence, and rather than asking for monetary compensation, he had his neighbor keep an eye on his place while he was away on vacation (at 80 ). Ellickson states that the "objective burden [he] bore in taking on additional boundary-fence maintenance is a rough measure of how much he valued his neighbor's service of keeping his eye on his house while he was away on vacation" (at 172). Maybe. But maybe not. A weaker explanation might be that the fence repair was objectively worth more, but the repairing neighbor did not insist on equal value in return in this round, or in any round in the near future. The accounts, in other words, may be looser; they may balance only roughly, and only over a very long period of time.

Burns, in the article excerpted above, also adds the commonsense point that in some social roles behavior cannot be explained by reference to self-interested exchange. One example he mentions is the giving of Christmas gifts, which may look like exchange but probably is not. I think he has a point. In my experience anyway, richer relatives don't "calibrate" the level of gift they give depending on what they will get in return. They consistently give more expensive gifts, and appear happy doing so. Likewise a retiring employee who receives a gift from younger colleagues may not be expected to reciprocate, and yet fellow employees often give generously. Funeral flowers and organ donations are perhaps the ultimate examples of gifts that cannot be reciprocated. Other examples are too numerous to mention, but the general point must be conceded that the sociologists probably have this one right: exchange can be economic or

35. Id. at 137. Note that one could infer that, in the long run, accounts will eventually be squared, and that the way to square these observations with Ellickson's hypothesis is to extend the time frame of the "game," perhaps even intergenerationally. But note how this takes on the appearance of circularity: we assume the actors are rational, and keep looking until our assumption is borne out.

36. Many others have done so. See, e.g., Cooter, 25 Law \& Soc'y Reu. 783 n. 62 (cited in note 2) (tit-for-tat, sometimes escalating to violence, is usual form of dispute resolution/ cooperation among native people of Papua New Guinea). 
social, or some mix of the two, but it is not always based strictly on selfinterest. And, in contrast to Ellickson's formulation, these exchanges take place without the giving of "side payments" to "even up" the parties' mental debit and credir ledger. ${ }^{37}$

Ellickson acknowledges this. He states that he will not attempt to account for norms of "pure charity"; while they may have an underlying economic logic (i.e., long-term reciprocity, or crude insurance), he elects to treat them essentially as "givens." Ellickson also proposes to ignore "distributional" concerns when analyzing exchanges. This neatly carves out a problem area but leaves an unsatisfying feeling. The primary goal of some exchanges is distributional. Can the cultural value behind this goal be ignored in other, more "economic" exchanges? More to the point, what norm operates to separate gift exchanges from economic exchanges? Ellickson's agnosticism on this issue leaves it for someone else to apply his thinking fully to the realm of gifts. Doing so might illuminate the content and possible efficiency of the meta-norm that separates gifts from true exchanges.

Putting foundational problems aside, Ellickson's hypothesis invites criticism and-as he states-empirical testing. ${ }^{38}$ It is not difficult to come up with examples of norms that seem at first glance inconsistent with wealth maximization. Consider some well-known examples. In some cultures-including peasant Sicily and inner city U.S.A.-escalating and vengeful revenge "games" are the norm; death is the not infrequent final "payoff." Can this really maximize wealth?339 In rural Ireland of the 19th century, land was divided among each of the male heirs, which was a major contributing factor in the Irish potato famine.

37. It should be noted that on one account, these seemingly nonrationally motivated acts have a rational basis: they label those who perform them as "good risks" for inclusion in future transactions with others. See Robert H. Frank, "Melding Sociology and Economics: James Coleman's Foundations of Social Theory," 30 J. Econ. Lit. 147 (1992). Coleman's views, incidentally, are quite consonant with Ellickson's, which shows that at least some sociologists share Ellicksson's "strong rationality" view of social interactions. See Swedberg, Economics and Sociology (cited in note 8). In fact, there is a rich body of contemporary scho!arship emphasizing the limits of strong rationality views of norms and institutions. See, e.g., Kenneth J. Koford \& Jeffrey B. Miller, eds., Social Norms and Economic Institutions (Ann Arbor: University of Michigan Press, 1991); Sharon Zukin \& Paul DiMaggio, eds., Structure of Capital: The Social Organization of the Economy (Cambridge: Cambridge University Press, 1990).

38. To be fair, Ellickson does consider two pieces of "counterevidence"-field research that purports to show some very amoral, greedy and selfish behavior among peasants in southern Italy and native peoples in Uganda (at 268). But the examples are drawn from attempts to refute "functionalist" theories in sociology, and so are directed at a slightly different target. On this debate over functionalism, see Jon Elster, "Social Norms and Economic Theory," 3 J. Econ. Perspectives 99 (1989).

39. Honvitz, Social Control 129, 131 (cited in note 19) ("vengeful self help ... proliferates in settings that lack legitimate state authority. For example, in peasant areas of southern Italy no neutral third parties are present to resolve disputes"). 
These examples call to mind the limits of the wealth-maximizing norm hypothesis. Revenge games are in fact a good case in point for the Hobbesian, state-centered view that Ellickson explicitly rejects; current events in Eastern Europe are perhaps another example. One might argue that the point of these norms is to present a few graphic illustrations of what happens to those who break the rules. Maybe the violent denouements are so easy to remember that they lower the informational costs associated with calculating the consequences of norm violations. But I doubt it. In any case they pose a stark test case for the Ellickson hypothesis.

The case of the Irish potato famine is closer to the examples Ellickson himself uses, however. The only real attempt he makes to deal with this sort of norm comes in the context of a discussion of magic, brutal rites, and the like. Ellickson says that these clearly non-wealth-maximizing norms can be "corrected" with more information: "The hypothesis [of wealth-maximizing norms] predicts that, if they become better educated in science, members of a preliterate tribe would tend to abandon old practices that their new knowledge had revealed to be welfare-reducing" (at 269).

Note two things about this passage: first, it makes no pretense at predicting when a society will adopt a norm of information acquisition. This is admittedly almost impossible, yet it raises once again the issue of metanorms that surrounds Ellickson's enterprise-what norms produce the "workaday" norms on which Ellickson's hypothesis is meant to be applied? Second, it provides an easy out for any norm that does not fit the hypothesis. If a norm reflects bad scientific information, it is not a candidate for testing. Yet this leads at its limits to a form of solipsism: only "rational" norms can be tested for their compliance with the hypothesis of rationality.

\section{CONCLUSION}

But again, the real argument is with the scope of Ellickson's claims, not their validity in light of his observations. Undoubtedly, the norms he studies grow out of self-interested exchange in a realm close to the purely economic. And undoubtedly, these norms can be usefully seen as emergent properties of repeat-play games. Assuming some dividing line can be arrived at, Ellickson will have to be acknowledged as a pioneer on the law and economics of nongift exchange norms. Casual empiricism within the sphere of his observations bears him out at every turn. Just since reading the book, I have discussed his ideas with the farmer from whom I buy hay mulch, and with my wife's aunt, who has a small farm in Canada. In both cases, I have been surprised that reciprocity of the tit-for-tat variety does 
seem to be present in at least some rural economic interactions. My wife's aunt, for instance, told me that her neighbor, who uses (gratis) some of her land for cattle, had refused to sell her some of his hay crop when supplies were short; in response, she moved the fence back some distance, thus shrinking the cattle field. And, consistent with Ellickson's thesis, neither she nor her neighbor gave a thought to their legal rights, for example, a potential reliance claim or the like by the neighbor.

The upshot is that Shasta County may not be a microcosm of the world, but it holds the promise of representing at least a fair slice of rural economic life in the Northern Hemisphere. In other words, one can argue with how far Ellickson's observations can be extended with the help of game theory, but one must first acknowledge that he has performed that rarest of feats: he has opened his eyes to the world-maybe not to all features of the world, or to the whole world, but at least some aspects of some of it. Read the book and you too will see. Who knows, it might even get you out to repair a fence or two. 
HeinOnline -- 18 Law \& Soc. Inquiry 3181993 